\title{
An equation for determining methane densities in fluid inclusions with Raman shifts
}

Jianli Zhang ${ }^{\text {a, b }}$, Shaohua Qiao ${ }^{c}$, Wanjun Lu ${ }^{\mathrm{d},}$, Qingcheng Hu ${ }^{\mathrm{a}}$, Shuguang Chen ${ }^{\mathrm{a}, \mathrm{b}}$, Yuan Liu ${ }^{\mathrm{a}}$

\begin{abstract}
Raman shift of the C-H symmetric stretching band $\left(v_{1}\right)$ of methane can be used to calculate the pressure and density of methane in fluid inclusions. However, previous numerical functions for Raman band shifts and methane density are only suitable for methane with densities lower than 0.3 $\mathrm{g} / \mathrm{cm}^{3}$. In this study, Raman shifts for pure $\mathrm{CH}_{4}$ were systematically measured at $25^{\circ} \mathrm{C}$ and pressures up to $150 \mathrm{MPa}$. Parameters of the long range attractive forces were fitted, and Raman shifts of $\mathrm{CH}_{4}$ were calculated with hard sphere model for density up to $0.55 \mathrm{~g} / \mathrm{cm}^{3}$. Based on experimental data and theoretical calculation, a unified equation was established to calculate the density of methane gas from Raman shifts over a wide density ranges up to $0.55 \mathrm{~g} / \mathrm{cm}^{3}$ :
\end{abstract}

$$
D=v_{d}-v_{o}=211.3 \rho^{4}-73.238 \rho^{3}+24.477 \rho^{2}-29.0632 \rho
$$


23 Where $\rho$ represents the density of methane in $\mathrm{g} / \mathrm{cm}^{3} ; D\left(\mathrm{~cm}^{-1}\right)$ is the difference between the meaured

24 peak position of methane in the fluid inclusion $\left(v_{d}\right)$ and the known peak position of methane at quite

25 low density $\left(v_{o}\right)$. The equation will work regardless of which machine the measurements of Raman

26 shifts are done on, as long as the user knows or finds the zero-density peak position.

27 Keywords: Fluid inclusion; Methane density; Raman shifts; Unified equation; $\mathrm{Pb}-\mathrm{Zn}$ deposit. 
Raman spectroscopy is a non-destructive technique to study individual fluid inclusions

30 (Roedder, 1990), especially small fluid inclusions $(\leq 3 \mu \mathrm{m})$ which are difficult to analyze with the

31 micro-thermometry technique (Wopenka et al., 1990). The presence of water in methane-rich

32 inclusions could cause the difficulty in methane density determination with micro-thermometry: at

33 low temperature water forms ice or clathrate, modifies the density of the methane-bearing phase, and

34 it is difficult to get an accurate homogenization temperature when ice or clathrate occurs in the vapor

35 phase in small inclusions. Raman parameters, such as peak intensity (area) ratio, peak width ratio,

36 and peak position, can be used to determine the properties of $\mathrm{CH}_{4}$-bearing fluid inclusions, for

37 example, compositions in gas mixtures of $\mathrm{CH}_{4}-\mathrm{CO}_{2}$ and $\mathrm{CH}_{4}-\mathrm{N}_{2}$ system (Seitz et al., 1993, 1996),

38 concentration of dissolved methane in water solution (Dubessy et al., 2001; Guillaume et al., 2003;

39 Lu et al., 2006), and the pressure of methane (Fabre and Couty, 1986; Fabre and Oksengorn, 1992;

40 Hansen et al., 2001; Lin et al., 2007; Lu et al., 2007).

41 Lu et al. (2007) established a unified equation for calculating methane pressures in the

$42 \mathrm{CH}_{4}-\mathrm{H}_{2} \mathrm{O}$ system from Raman shifts for the C-H symmetric stretching band of methane. However,

43 the pressure range of most previous measurements is just from 0 to $70 \mathrm{MPa}$, and the corresponding

44 methane densities are lower than $0.3 \mathrm{~g} / \mathrm{cm}^{3}$, so their equations do not apply to the inclusions with

45 density higher than $0.3 \mathrm{~g} / \mathrm{cm}^{3}$.

46 In this study, we measured Raman shifts of pure methane at pressures up to $150 \mathrm{MPa}$ at $25^{\circ} \mathrm{C}$.

47 With the new data and theoretical calculation, we established an equation which could be also 48 applied in other laboratories for determining the density of methane in pure $\mathrm{CH}_{4}$ fluid inclusions. The

49 new equation was effectively applied to determine the density of four typical pure $\mathrm{CH}_{4}$ inclusions in 50 two samples obtained from a MVT-Pb-Zn deposit in mid-south China.

\section{2. Methods}

$52 \quad 2.1$ Experimental apparatus and procedures 
The apparatus and procedures are similar to those used in the study of Lu et al. (2007) (Fig. 1).

54 Experiments were carried out with a capillary high-pressure optical cell (HPOC; Chou et al., 1990, 55 2005). After the capillary cell and pipeline were evacuated, methane (99.99\%, Air Products) was 56 loaded into the cell and Raman spectra were collected under high pressures gradually up to $150 \mathrm{MPa}$.

57 The methane pressure in the optical cell was adjusted by a high pressure generator and monitored by 58 an Omega PX91N0-50KSV digital pressure transducer (on a full scale of $400 \mathrm{MPa}$, accurate to \pm 0.5

$59 \%)$. The temperature in the cell was controlled by a Linkam CAP 500 heating-cooling stage with an 60 accuracy of $\pm 0.1{ }^{\circ} \mathrm{C}$ at $25^{\circ} \mathrm{C}$ (Lu et al., 2013).

\subsection{Spectra collection and calibration}

Raman spectra of gas were collected with a JY/Horiba LabRam HR 800 system provided with

$63532.06 \mathrm{~nm}$ laser (Nd: YAG) which produces approximately $15 \mathrm{~mW}$ laser excitation on the surface of 64 the sample cell. The detector is an electronically-cooled CCD detector, operating normally at $-70{ }^{\circ} \mathrm{C}$. 65 An 1800 groove/mm grating with a spectral resolution of about $0.65 \mathrm{~cm}^{-1}$, a narrow slit $(50 \mu \mathrm{m})$ and an Olympus $50 \times$ objective with a numerical aperture of 0.5 were used. Raman spectra were collected from 2750 to $3050 \mathrm{~cm}^{-1}$, simultaneously with two emission lines from a neon lamp as calibration reference at $626.56 \mathrm{~nm}\left(2836.9888 \mathrm{~cm}^{-1}\right)$ and $633.36 \mathrm{~nm}\left(3008.1274 \mathrm{~cm}^{-1}\right)$, respectively.

69 Each Raman peak wave number $v_{\text {true }}$ for the symmetric stretching bands of $\mathrm{CH}_{4}$ was calibrated with 70 the following equation (Kim et al., 1986):

$$
\frac{v_{\text {true }}-2836.9888}{v_{1}-N e_{1}}=\frac{3008.1274-2836.9888}{N e_{2}-N e_{1}}
$$

$$
\begin{gathered}
\text { (1), } \frac{v_{\text {true }}-2836.9888}{v_{1}-\mathrm{Ne}_{1}}= \\
\frac{3008.1274-2836.9888}{\mathrm{Ne}_{2}-\mathrm{Ne}_{1}} \text { (1) }
\end{gathered}
$$

Where, $v_{1}$ is the observed wave number of methane, $\mathrm{Ne}_{1}$ and $\mathrm{Ne}_{2}$ are two measured lines corresponding to the neon lamp scattering bands on $626.56 \mathrm{~nm}$ and $633.36 \mathrm{~nm}$, respectively.

\subsection{Theoretical calculation}


There have been a lot of experimental studies on the relationship between Raman peak position and methane density. All nine data sets collected from the literature and from this study indicate that peak positions of $\mathrm{CH}_{4}$ shift to lower relative wave numbers as a function of increasing density (Fig. 2). Theoretically, the trends of these data sets are same, though the instrumental parameters vary in different laboratories.

Molecular vibrations in methane gas are influenced by its surrounding composition and density (Seitz et al., 1996; Hansen et al., 2001). Isolated molecule often becomes closer to each other at increased densities or pressures, and an average force exerted by its surrounding molecules causes a frequency shift of the molecular vibrations. On the basis of a theoretical model — the perturbed hard sphere model, developed by Schweizer and Chandler (1982), the density dependence of Raman shifts of simple molecules had been studied since the 1980s, such as benzene (Zakin et al., 1985), pyridine (Zakin et al., 1986), methanol (Zerda et al., 1987) in solutions; and nitrogen (Devendorf and Ben-Amotz, 1993), methane, ethane (Ben-Amotz et al., 1992) in supercritical fluids.

Generally, in hard sphere model, a solute stands for an approximate pseudo-diatomic molecule, composed of two hard spheres (diameters of $\sigma_{1}$ and $\sigma_{2}$ respectively) and a bond length $r_{12}$. It is dissolved in a hard sphere solvent (infinite dilution; diameter $\sigma_{s}$ ) with the density of $\rho\left(\mathrm{g} / \mathrm{cm}^{3}\right)$. However, for pure fluids, the solute and solvent molecules are the same. According to hard sphere model, the frequency shift resulted from the symmetrical stretching vibration of the "diatomic" solute dilute in a solvent is a sum of the two contributions (Ben-Amotz et al., 1992):

$$
\Delta v=\Delta v_{R}+\Delta v_{A}
$$

where $\Delta v$ stands for total frequency shifts, $\Delta v_{R}$ and $\Delta v_{A}$ represent frequency variations caused by the repulsive force (close-range) and attractive force (long-range), respectively. The frequency shift contribution of repulsive force can be calculated by the following function: 


$$
\Delta v_{R}=v_{0} \frac{F_{R}}{f}\left[-\frac{3 g}{2 f} f_{1}(\kappa)+\frac{G_{R}}{F_{R}} f_{2}(\kappa)\right]
$$

103 where $v_{0}$ is the unperturbed vibrational frequency shift of single solute (pure $\mathrm{CH}_{4}$ fluid) in

104 low density vapor phase; $f$ and $g$ represent the intra-molecular quadratic force-constant

105 (harmonic vibration) and the cubic force-constant (anharmonic vibration), respectively, which can be obtained from measured vibrational frequencies and bond lengths with extended Barger's rule correlations (Herschbach et al., 1961). $f_{1}(\kappa)$ and $f_{2}(\kappa)$ are the modified Morse coefficients for anharmonic vibrations (Buckingham et al., 1958). As a function of the solute

109 bond length, constants $F_{R}$ and $G_{R}$ represent the linear and quadratic coefficients of the potential energy of mean force, respectively.

111 For the case of diatomic solute, the attractive force frequency shift $\Delta v_{A}$ is proportional

112 to the force $\left(F_{\mathrm{A}}\right)$ along the bond, because $F_{\mathrm{A}}$ is relatively varying slowly when the density is

113 lower. And according to the state of equation of van der Waals, $\Delta v_{A}$ is as a linear function of

114 methane density. However, the attractive force contribution of $\mathrm{C}-\mathrm{H}$ stretching vibration 115 should be approximately quadratic rather than linear dependence on methane density 116 (Ben-Amotz and Herschbach, 1993). The quadratic function is extrapolated as follows (Fig. $1173)$ :

$$
\Delta v_{A}=\Delta v-\Delta v_{R}=a \rho^{2}+b \rho
$$

119 where $\Delta v$ is the measured total frequency shifts, $\Delta v_{R}$ is the repulsive force frequency shift

120 calculated with Eq.3. Parameters $a$ and $b$ can be fitted with the vibrational frequency shifts 121 measured in this study, as other molecular parameters (Table 1) can be quoted from the 122 literature (Buckingham, 1958; Ben-Amotz et al., 1992). The relationship between frequency 123 shifts and fluids densities at high pressure conditions can be predicted with this model.

\section{3. Results and discussion}

\subsection{Unified equation for near room temperature}


With the new data and theoretical calculation, we can establish an equation which could be applied in all laboratories for determining the density of methane. Following the procedures of Lu et al. (2007), we fitted the relationship between $D_{\mathrm{k}, \mathrm{j}}$ (the difference between the measured shift $v_{k, j}$ of $k$ th data point of the $j$ th data set, and the Raman position $v_{o_{j}}$ near zero-density of the $j$ th data set) and density $\rho_{\mathrm{k}, \mathrm{j}}$. The measured data in this study were used to derive the initial coefficients $C_{i}(i=1-4)$ of a four-order polynomial function:

$$
D_{k, j}=v_{k, j}-v_{o_{j}}=\sum_{i=1}^{4} C_{i} \rho_{k, j}^{i}, \quad j=1,2,3, \cdots, 10
$$

We repeatedly fitted the data to Eq. (5), until the relation between deviation $D_{\mathrm{k}, \mathrm{j}}\left(\mathrm{cm}^{-1}\right)$ and density $\rho_{\mathrm{k}, \mathrm{j}}\left(\mathrm{g} / \mathrm{cm}^{3}\right)$ of all data sets can fit the polynomial equation. Data up to $0.55 \mathrm{~g} / \mathrm{cm}^{3}$ used in the fitting were calculated values from the hard-sphere model. We got the following polynomial equation to calculate the density of pure $\mathrm{CH}_{4}$ with Raman shifts (Fig. 4):

$$
D=v_{d}-v_{o}=211.3 \rho^{4}-73.238 \rho^{3}+24.477 \rho^{2}-29.063 \rho
$$

with $R^{2}=0.9988$, where $D\left(\mathrm{~cm}^{-1}\right)=v_{\rho}-v_{o}$ represents the difference between the peak positions at increasing densities $\left(v_{\rho}\right)$ and near zero density $\left(v_{o}\right) ; \rho$ is the density of pure $\mathrm{CH}_{4}$.

140 The peak positions for some data sets near zero density $v_{o}$ (Table 2) were calculated using 141 the similar procedures in Lu et al. (2007). The density-depended Raman shifts (Ds) calculated 142 with this polynomial equation, can reproduce both experimental data and values predicted 143 from theoretical hard sphere model (Fig. 4), including high density region $\left(>0.4 \mathrm{~g} / \mathrm{cm}^{3}\right)$ where 144 experimental data are not covered.

145 Once the frequency shift $v$ of methane in fluid inclusion is measured in a lab, $D$ value 146 in Eq. 6 could be obtained if the peak position near zero density $v_{o}$ for the Raman system was 147 calibrated with a referenced methane-bearing sample (details were described in Lu et al., 148 2007), the density of methane in the inclusion can be conveniently determined from Fig. 4 149 and Eq. 6, e.g., using half-interval search method. It is worth noting that, for a specific $D$, 
150 there could be two possible values of density in the range of $0 \sim 0.55 \mathrm{~g} / \mathrm{cm}^{3}$ which satisfy the

151 Eq. 6, one solution is smaller than $0.37 \mathrm{~g} / \mathrm{cm}^{3}$ and the other solution is larger than $0.37 \mathrm{~g} / \mathrm{cm}^{3}$.

152 To determine the right solution, the value of full width at half height (FWHH) of methane $v_{1}$

153 band could be used as a reference, since the value of full width at half height is increase with

154 the density of methane (Fig. 5). But one should be keep in mind that, the FWHH of methane

155 is not only the function of density, but also changes with the instrumental seting, e.g., the

156 wavelength of the laser, the numerical aperture of objective, the slit width, the groove density

157 of grating, the resolution of CCD detector used, and so on.

\subsection{Error analysis}

Accuracy of the $\mathrm{CH}_{4}$ density inside a natural inclusion determined with measured Raman

160 shift with Eq. 6 will be affected by two factors. One is the accuracy of the measurement of

$161 \mathrm{CH}_{4}$ peak position, the other is the accuracy of the calculation using Eq. 6.

For the accuracy of the measurement of $\mathrm{CH}_{4}$ peak position, it usually depends on the resolution of Raman spectrometer, as Dubessy et al. (2012) noted that "The spectral resolution of a Czerny-Turner spectrometer does not only result from the groove density and focal distance of the spectrometer, but also from the width of the entrance slit and the

166 diameter of the confocal hole". He also pointed out the spectral resolution depends on both the excitation wavelength and Raman shift (Dubessy et al., 2012). In order to achieve a maximum precision, a high resolution grating (e.g., 1800 groove $/ \mathrm{mm}$ ) and a narrow slit (e.g., $50 \mu \mathrm{m}$ ) should be used during the measurement. Besides, peak positions were determined by

170 fitting the summed Gaussian-Lorentzian curve to each $\mathrm{CH}_{4}$ peak and calibrated with the 171 neon emission lines. The error of $\mathrm{CH}_{4}$ peak positions resulted from peak fitting $\left( \pm 0.01 \mathrm{~cm}^{-1}\right)$ and calibration $\left( \pm 0.02 \mathrm{~cm}^{-1}\right)$ is within a maximum value about $\pm 0.03 \mathrm{~cm}^{-1}$.

173 The accuracy of the $\mathrm{CH}_{4}$ density in pure $\mathrm{CH}_{4}$ inclusions calculated from eq. 6 can be 174 evaluated by the following derivation analysis: 
where, $a=211.3 ; b=-73.238 ; c=24.477 ; d=-29.063$.

$$
\frac{d \rho}{d \nu}=\frac{1}{4 a \rho^{3}+3 b \rho^{2}+2 c \rho+d}
$$

As in figure 6, the error of density was plotted with increasing density in the range 0 $0.55 \mathrm{~g} / \mathrm{cm}^{3}$, with a high accuracy $\left( \pm 0.03 \mathrm{~cm}^{-1}\right)$ and a lower one $\left( \pm 0.3 \mathrm{~cm}^{-1}\right)$ of $\mathrm{CH}_{4}$ peak position, respectively. The density error of methane is quite small when the accuracy of $\mathrm{CH}_{4}$ peak position is as small as $\pm 0.03 \mathrm{~cm}^{-1}$ (full line, Fig. 6) in the ranges of $0 \sim 0.32 \mathrm{~g} / \mathrm{cm}^{3}$ and $0.4 \sim 0.6 \mathrm{~g} / \mathrm{cm}^{3}$. The density error is relatively bigger (about $10 \%$ ) in the range of $0.1 \sim 0.32$ $\mathrm{g} / \mathrm{cm}^{3}$ when the accuracy of $\mathrm{CH}_{4}$ peak position is $\pm 0.3 \mathrm{~cm}^{-1}$ (dashed line, Fig. 6). However, in the range of $0.32 \sim 0.40 \mathrm{~g} / \mathrm{cm}^{3}$, the error is large, and the accuracy of density calculated with Eq. 6 is much lower.

\subsection{The effect of temperature on $\mathrm{CH}_{4}\left(v_{1}\right)$ peak position shifts}

The above Eq. 6 is obtained from and suitable for near room temperature studies. In order to investigate the temperature effect on the Raman shifts of $\mathrm{CH}_{4}$, Raman spectra of pure $\mathrm{CH}_{4}$ fluid (in a HPOC) were collected from 25 to $200{ }^{\circ} \mathrm{C}$ at pressures up to140 $\mathrm{MPa}$. And the neon emission lines were collected simultaneously with each $\mathrm{CH}_{4}$ spectra throughout the analytical session. The result shows that the $\mathrm{CH}_{4}\left(v_{1}\right)$ peak position shifts to the higher wavenumbers as the temperature increases at constant pressure (Fig. 7) and density (Fig. 8). The temperature effect becomes larger at higher density or pressure, which agree with the previous observations (Shang et al., 2014). As temperature increases from 25 to $100{ }^{\circ} \mathrm{C}$, D in Eq. 6 deceases $0.47 \mathrm{~cm}^{-1}$ at density of $0.06 \mathrm{~g} / \mathrm{cm}^{3}$, and $0.96 \mathrm{~cm}^{-1}$ at $0.30 \mathrm{~g} / \mathrm{cm}^{3}$. We can deduce that, for room temperature study, the difference between $D$ at $20{ }^{\circ} \mathrm{C}$ and $D$ at $25{ }^{\circ} \mathrm{C}$ is from 0.031 to $0.064 \mathrm{~cm}^{-1}$ for density in the range from 0.06 to $0.30 \mathrm{~g} / \mathrm{cm}^{3}$, such difference has very small effect on the density calculation. However, the effect of temperature should be taken into account at high temperatures. 


\section{Applications}

Microthermometry coupled with thermodynamic modeling and Raman spectroscopy are complementary and efficient methods in the study of fluid inclusions (Roedder, 1980; van den Kerkhof, 1990; Wopenka et al., 1990; Burke, 2001), parameters of methane fluid inclusions obtained from micro-thermometry and Raman spectroscopy can be used to reconstruct the P-T conditions of methane-bearing fluid migration in sedimentary basins (Roedder E., 1990; Pironon et al., 2000; Dubessy et al., 2001) and metamorphic environments (Crawford et al., 1981).

\subsection{Determination of density of pure $\mathrm{CH}_{4}$ inclusions with Raman shifts}

Quartz or fluorite in MVT deposit often trapped inclusions with hydrocarbons (Roedder et al., 1984). We observed some $\mathrm{CH}_{4}$ fluid inclusions (typically 5-20 $\mu \mathrm{m}$ in the maximum dimension, Figs 9\&10) hosted within a quartz vein and a fluorite vein from ore samples of a MVT Pb-Zn deposit in Sangzhi \& Shimen synclinorium tectonic district, north of Hunan province, China.

Four individual fluid inclusions, $\mathrm{CH}_{4}-\mathrm{A}$ and $\mathrm{CH}_{4}-\mathrm{B}$ in quartz (Fig.9) and the other two $215 \mathrm{CH}_{4}-\mathrm{C}$ and $\mathrm{CH}_{4}$-D in fluorite (Fig.10) from the two samples were studied with Raman 216 spectroscopy. Firstly, a 300 groove/mm grating and a spectral window of $0 \sim 4000 \mathrm{~cm}^{-1}$ by 217 Raman spectroscopy were adopted to check whether the gas inside the inclusions was pure $218 \mathrm{CH}_{4}$ or not. The Raman spectra (Fig.11) indicated that the four individual inclusions are pure 219 methane inclusions. Secondly, the inclusions were both studied with a 1800 groove/mm 220 grating and a spectral window of $2750 \sim 3050 \mathrm{~cm}^{-1}$ and a narrow slit around $50 \mu \mathrm{m}$, calibrated 221 with the neon lamp at $25^{\circ} \mathrm{C}$ (Fig.12).

Using the unified equation (Eq.6), we calculated the internal density of these four inclusions $\rho_{1}$ (A: $0.2719 \mathrm{~g} / \mathrm{cm}^{3}, \mathrm{~B}: 0.2712 \mathrm{~g} / \mathrm{cm}^{3}$; C: $0.026 \mathrm{~g} / \mathrm{cm}^{3}, \mathrm{D}: 0.0249 \mathrm{~g} / \mathrm{cm}^{3}$ ) from the

224 measured peak position and with reference to the peak width of $\mathrm{CH}_{4}$ (Table 3). 


\subsection{Low temperature phase transition analysis of pure $\mathrm{CH}_{4}$ inclusions}

For comparison, we also observed the phase transitions of natural pure $\mathrm{CH}_{4}$ fluid inclusions at low temperatures controlled by the Linkam CAP 500 heating-cooling stage. Figure 13 illustrates the phase transition process of pure $\mathrm{CH}_{4}$ fluid inclusions in quartz at low temperatures in details. Inclusion $\mathrm{A}$ and $\mathrm{B}$ homogenized to the liquid phase; while $\mathrm{C}$ and $\mathrm{D}$ 230 homogenized to the vapor phase. It is apparent that the homogenization temperature (Table 4) 231 of each $\mathrm{CH}_{4}$ inclusion is far below the critical point of $\mathrm{CH}_{4}$ at $-82.1^{\circ} \mathrm{C}$ (van den Kerkhof, 232 1990) or $-82.599{ }^{\circ} \mathrm{C}$ (Friend et al., 1989). The corresponding bulk density of the four 233 inclusions $\rho_{2}$ (Table 4) were calculated from the computer programs for fluid inclusions 234 studies FLUIDS (Bakker et al., 2003), using equation of state of Setzmann \& Wagner (1991).

\subsection{Comparison between Raman spectroscopy and micro-thermometry}

It is obvious that the densities of $\mathrm{CH}_{4}$ inclusion $\mathrm{A}$ and $\mathrm{B}$ are much higher than the critical density of methane $\left(0.163 \mathrm{~g} / \mathrm{cm}^{3}\right)$; while the densities of $\mathrm{C}$ and $\mathrm{D}$ are much lower than it. But on the whole, the densities of the four pure $\mathrm{CH}_{4}$ fluid inclusions calculated with Raman shifts agree with the values from micro-thermometry (Table 3, Table 4).

According to the error analysis, the achievable maximum precision of measured $\mathrm{CH}_{4}$ peak position is $\pm 0.03 \mathrm{~cm}^{-1}$, the corresponding accuracy of density of the fluid inclusions 242 should be $\pm 0.0025 \mathrm{~g} / \mathrm{cm}^{3}$. For the temperature below the critical point of $\mathrm{CH}_{4}$ at $-82.1^{\circ} \mathrm{C}$, the 243 accuracy of measurements of the heating-cooling stage is about $\pm 0.5^{\circ} \mathrm{C}$, the corresponding 244 accuracy of the calculated density is about $\pm 0.0034 \mathrm{~g} / \mathrm{cm}^{3}$. It can be seen that methane density 245 calculated with Raman shifts has a similar accuracy to that calculated with micro 246 thermometry. Similar to the accuracy of Raman spectroscopic method we discussed above, 247 the accuracy of micro-thermometry method depends on not only the accuracy of 248 measurements of homogenization temperature, but also the thermodynamic model (Equation 249 of state) used to calculate the methane density at the homogenization temperature. Since 
methane density near the critical density $\left(0.163 \mathrm{~g} / \mathrm{cm}^{3}\right)$ is very sensitive to the homogenization 251 temperature, it is difficult to accurate determine the sample density from 0.09 to $0.163 \mathrm{~g} / \mathrm{cm}^{3}$ via micro-thermometry; however, Raman spectroscopic method can give a satisfied result.

\section{Conclusions}

This paper presents a unified equation to determine methane densities up to $0.55 \mathrm{~g} / \mathrm{cm}^{3}$ in fluid inclusions with measured Raman shifts, based on on experimental data and theoretical calculation. The key advantage is that the proposed equation will work regardless of which machine the measurements are done on, as long as the user knows an estimate for the zero-density peak position. The equation was successfully applied to calculating the densities of two individual natural methane inclusions in quartz vein with high densities and fluorite vein with low densities in a MVT mineral deposit. Unfortunately, at present we did not get a good sample to demonstrate using the equation to calculate the density of methane higher than $0.3 \mathrm{~g} / \mathrm{cm}^{3}$, but we believe that the equation can also be applied to those fluid inclusions formed in deep geological environments, for example, the inclusions in mantle minerals such as olivine, diamond. Sachan et al. (2007) observed some inclusions in harzburgite, which preserved methane generated during serpentinization of upper mantle rocks, the density is $0.473 \mathrm{~g} / \mathrm{cm}^{3}$ for one observed inclusion with homogenization temperature of $-160{ }^{\circ} \mathrm{C}$. In such cases, Raman spectroscopic method can be used to get accurate density information.

\section{Acknowledgments}

We thank Dr. I-Ming Chou and Dr. R.C. Burruss for their kind help and guidance for many years on the Raman spectroscopic research on Geo-fluids. We also thank Prof. Jean Dubessy and two other reviewers for their valuable suggestions and constructive comments.

273 This work is partly supported by the National Sciences Foundation of China (No. 41102154, 274 41176047), the Key Project of Chinese Ministry of Education (No. 109108), and the 
275 Programme of Introducing Talents of Discipline to Universities (No. B14031) by Ministry of 276 Education.

277

278 


\section{References}

280 Bakker, R.J., 2003. Package FLUIDS1. Computer programs for analysis of fluid inclusion data and for modeling bulk fluid properties. Chem. Geol. 194, 3-23.

282

Ben-Amotz, D., Herschbach, D. R., 1993. Hard fluid model for solvent-induced shifts in molecular vibrational frequencies. J. Phys. Chem. 97, 2295-2306.

Ben-Amotz, D., La Plant, F., Shea, D., Gardecki, J., List, D., 1992. “Supercritical Fluid Technology", ACS Symposium Series. Eds. F. V. Bright, and M. E. McNanlly. American Chemical Society, Washington, DC, 488, 18-30.

Buckingham, A.D., 1958. Solvent effects in infra-Red Spectroscopy. Proceedings of the Royal Society of London. Series A. Mathematical and physical Sciences 248, 169-182.

Burke, E. A. J., 2001. Raman microspectroscopy of fluid inclusions. Lithos, 55: 139-158.

Chou, I.M., Pasteris, J.D., Seitz, J.C., 1990. High density volatiles in the system C-O-H-N for the calibration of a laser Raman microprobe. Geochim. Cosmochim. Acta., 54, 535-543.

Chou, I.M., Burruss, R.C., Lu, W.J., 2005. A new optical cell for spectroscopic studies of geologic fluids at pressures up to $100 \mathrm{MPa}$ In: Chen, J., Wang, Y., Duffy, T.S., Shen, G., and Dobrzhinetskaya, L.F. (eds.), Advances in High-Pressure Technology for Geophysical Applications, Elsevier, Amsterdam, 24, 475-485.

Crawford, M. L., 1981. Fluid inclusions in metamorphic rocks-low and medium grade. In: Hollister, L. S. and Crawford, M. L (eds.), Short Course in Fluid Inclusions: Applications to Petrology. Mineralogical Association of Canada, 157-181.

Devendorf, G.S., Ben-Amotz D., 1993. Vibrational frequency shifts of fluid nitrogen up to ultrahigh temperatures and pressures. J. Phys. Chem. 97, 2307-2313.

Dubessy, J., Buschaert S., Lamb W., Pironon J., Thiéry R.., 2001. Methane-bearing aqueous fluid inclusions: Raman analysis, thermodynamic modeling and application to petroleum 
basins. Chem. Geol. 173, 193-205.

304 Dubessy, J., Caumon, M. C., Rull, F., Sharma, S., 2012. Instrumentation in Raman spectroscopy: Elementary theory and Practice. Raman Spectroscopy applied to Earth Sciences and Cultural Heritage, 83-172.

Fabre, D., Couty, R.., 1986. Etude, par spectroscopie Raman, du méthane comprimé jusqu'à 3

Fabre, D., Oksengorn, B., 1992. Pressure and Density Dependence of the $\mathrm{CH}_{4}$ and $\mathrm{N}_{2}$ Raman Lines in an Equimolar $\mathrm{CH}_{4} / \mathrm{N}_{2}$ Gas Mixture. Appl. Spectrosc. 46, 468-471.

Friend, D.G., Ely, J.F., Ingham, H., 1989. Thermophysical properties of methane. J. Phys. Chem. Ref. Data 18, 583-638.

Guillaume, D., Teinturier, S., Dubessy, J., Pironon, J., 2003. Calibration of methane analysis by Raman spectroscopy in $\mathrm{H}_{2} \mathrm{O}-\mathrm{NaCl}-\mathrm{CH}_{4}$ fluid inclusions. Chem. Geol. 194, 41-49.

Hansen, S. B., Berg R..W., Stenby, E. H., 2001. Raman spectroscopic studies of methane-ethane mixtures as a function of pressure. Applied Spectroscopy 55, 745-749.

Herschbach, D. R., Laurie, V. W., 1961. An harmonic potential constants and their dependence upon bond length. J. Chem. Phys. 35, 458-463.

Kim, S.B., Hammaker, R.M., Fateley,W.G., 1986. Calibrating Raman Spectrometers Using a Neon Lamp. Appl. Spectrosc. 40, 412-415.

Lin, F., 2005. Experimental Study of the PVTX Properties of the system $\mathrm{H}_{2} \mathrm{O}-\mathrm{CH}_{4}$. Virginia PolytechnicInstitute and State University (Ph. D thesis).

Lin, F., Bodnar, R.J., Becker S.P., 2007. Experimental determination of the Raman $\mathrm{CH}_{4}$ symmetric stretching $\left(\mathrm{v}_{1}\right)$ band position from 1-650 bar and $0.3-22{ }^{\circ} \mathrm{C}$ : Application to fluid inclusion studies. Geochim. Cosmochim. Acta., 71, 3746-3756. 
Aqueous Solutions under High Pressures via Raman Spectroscopy: A New Method for the Determination of Diffusion Coefficients of Methane in Water near Hydrate Formation Conditions. Appl. Spectrosc. 60, 122-129.

Lu, W., Chou, I.M., Burruss, R.C., Song, Y., 2007. A unified equation for calculating methane vapor pressures in the $\mathrm{CH} 4-\mathrm{H} 2 \mathrm{O}$ system with measured Raman shifts. Geochim.

Lu, W., Guo, H., Chou, I., Burruss, R.C., Li L., 2013. Determination of diffusion coefficients of carbon dioxide in water between 268 and $473 \mathrm{~K}$ in a high-pressure capillary optical cell with in situ Raman spectroscopic measurements. Geochim. Cosmochim. Acta., 72,

Pironon, J., Thiéry, R., Teinturier, S., Walgenwitz, F., 2000. Water in petroleum inclusions.

Mao, S., Duan, Z., Hu, J., Zhang, D., 2010. A model for single-phase PVTx properties of $\mathrm{CO}_{2}-\mathrm{CH}_{4}-\mathrm{C}_{2} \mathrm{H}_{6}-\mathrm{N}_{2}-\mathrm{H}_{2} \mathrm{O}-\mathrm{NaCl}$ fluid mixtures from 273 to $1273 \mathrm{~K}$ and from 1 to 5000

Sachan, H.K., Mukherjee, B.K., Bodnar. R. J., 2007. Preservation of methane generated during serpentinization of upper mantle rocks: Evidence from fluid inclusions in the Nidar ophiolite, Indus Suture Zone, Ladakh (India). Earth \& Planetary Sci. Let., 257, 1-2, 
354 Setzmann, U., Wagner, W., 1991. A New Equation of State and Tables of Thermodynamic Properties for Methane Covering the Range from the Melting Line to $625 \mathrm{~K}$ at Pressures up to 1000 MPa. J. Phys. Chem. Ref. Data, 20(6) pp. 1061-1155.

Shang, L.B., Chou, I.M., Burruss, R.C., Hu, R.Z., and Bi X.W., 2014. Raman spectroscopic characterization of $\mathrm{CH}_{4}$ density over a wide range of temperature and pressure. J. Raman Spectrosc., 45, 696-702.

Schweizer, K. S., Chandler D., 1982. Vibrational dephasing and frequency shifts of polyatomic molecules in solution. J. Chem. Phys. 76, 2296-2314.

Seitz, J. C., Pasteris, J. D., Chou, I. M., 1993. Raman spectroscopic characterization of gas mixtures. I. Quantitative composition and density determination of $\mathrm{CH}_{4}, \mathrm{~N}_{2}$, and their mixtures. Am. J. Sci. 293, 297-321.

Seitz, J. C., Pasteris, J. D., Chou, I. M., 1996. Raman spectroscopic characterization of gas mixtures. II. Quantitative composition and pressure determination of the $\mathrm{CO}_{2}-\mathrm{CH}_{4}$ system. Am. J. Sci. 296, 577-600.

Thieu, V., Subramanian, S., Colgate, S. O., Sloan, E. D. Jr., 2000. High-pressure optical cell for hydrate measurements using Raman spectroscopy. In Holder G. D., and Bishnoi P. R., (eds.), Gas Hydrates, Challenges for the Future, Ann. N.Y. Acad. Sci., 912, 983-992.

van den Kerkhof, A.M., 1990. Isochoric phase diagrams in the systems $\mathrm{CO}_{2}-\mathrm{CH}_{4}$ and $\mathrm{CO}_{2}-\mathrm{N}_{2}$ : application to fluid inclusions. Geochim. Cosmochim. Acta., 54, 621-629.

Wopenka, B., Pasteris, J.D., Freeman, J.J., 1990. Analysis of individual fluid inclusions by Fourier transform infrared and Raman microspectroscopy. Geochim. Cosmochim. Acta., $54,519-533$.

Zakin, M. R., Herschbach, D. R., 1985. Relation of vibrational frequency shifts to molecular compression in liquid benzene. J. Phys. Chem. 83, 6540-6541. 
378 Zakin, M. R., Herschbach, D. R., 1986. Vibrational frequency shifts induced by molecular 379 compression of pyridine in solution. J. Phys. Chem. 85, 2376-2383.

380 Zerda, T. W., Thomas, H. D., Bradley, M., Jonas, J., 1987. High pressure isotropic 381 bandwidths and frequency shifts of the $\mathrm{C}-\mathrm{H}$ and $\mathrm{C}-\mathrm{O}$ modes of liquid methanol. J. Phys. $382 \quad$ Chem. 86, 3219-3224. 


\section{FIGURE CAPTIONS}

Fig.1 Schematic diagram of the experimental system (modified from Lu et al., 2007).

Fig.2 Raman shift position of C-H symmetric stretching band $\left(v_{1}\right)$ of methane from 10 available data sets as a function of density. The density of methane is calculated from the computer program of Mao et al. (2010).

Fig.3 The measured total frequency shift $\Delta v$ in this study, the repulsive force frequency shift $\Delta v_{R}$ calculated with hard sphere model, and the derived attractive force frequency shift $\Delta v_{A}$, as a function of density of methane.

Fig.4 The polynomial equation fitted from ten data sets and theoretical calculation of the Raman shift.

Fig.5 $\mathrm{CH}_{4}$ peak width at half height measured in this study at $25^{\circ} \mathrm{C}$, and the values observed by Fabre et al., (1986) at $19.85^{\circ} \mathrm{C}$.

Fig. 6 Error of the calculated density (a) and the relative uncertainties (b), plotted with density of methane, for the different values of accuracy of $\mathrm{CH}_{4}$ peak position of $0.03 \mathrm{~cm}^{-1}$ (full line) and $0.3 \mathrm{~cm}^{-1}$ (dashed line).

406

407 Fig. 7 Raman spectra of methane at $80 \mathrm{MPa}$ from 25 to $200^{\circ} \mathrm{C}$. 
409 Fig.8 Raman position shift of methane at 25, 100, 160, and $200{ }^{\circ} \mathrm{C}$, together with previous 410 study of Lu et al.(2007) at 100 and $200^{\circ} \mathrm{C}$, and Shang et al.(2014) at $100{ }^{\circ} \mathrm{C}$.

412 Fig. 9 Photograph of natural $\mathrm{CH}_{4}$ fluid inclusions (A and $\mathrm{B}$ in the square frame) in quartz 413 from a MVT-Pb-Zn deposit basin under an Olympus $20 \times$ objective.

415 Fig. 10 Photographs of natural $\mathrm{CH}_{4}$ fluid inclusions ( $\mathrm{C}$ and $\mathrm{D}$ ) in fluorite from a MVT-Pb-Zn 416 deposit under an Olympus $50 \times$ objective.

418 Fig. 11 Raman spectra of four natural fluid inclusions, collected with 300 groove/mm grating.

Fig.12 Raman spectra of four individual natural fluid inclusions collected with an 1800 groove/mm grating.

423 Fig. 13 Illustrations of low-temperature phase transition under an Olympus $50 \times$ objective 424 (inclusions $\mathrm{A}$ and B). (a) Single -phase $\mathrm{CH}_{4}$ inclusions at $25^{\circ} \mathrm{C}$; (b) Bubbles appeared when 425 frozen to $-101.5^{\circ} \mathrm{C}$; (c) Bubbles got bigger in size at $-125^{\circ} \mathrm{C}$ ); (d) Bubbles remained constant at $-193.3{ }^{\circ} \mathrm{C}$; (e) Bubbles decreased in size when heated from $-193.3{ }^{\circ} \mathrm{C}$ to $-112.5{ }^{\circ} \mathrm{C}$; (f) Bubbles became smaller $\left(-101^{\circ} \mathrm{C}\right)$; $(\mathrm{g})$ Bubbles almost disappeared $\left(-99.2^{\circ} \mathrm{C}\right)$; (h) Bubble in A disappeared at $-98.1^{\circ} \mathrm{C}$; (i) Bubble in B disappeared at $-97.9^{\circ} \mathrm{C}$. Both of inclusions $\mathrm{A}$ and 429 B homogenized to the liquid phase. 
Table 1 Parameters used in hard sphere model for calculating density-depended Raman shifts.

\begin{tabular}{cccccccccccc}
\hline mol & bond & $\begin{array}{c}T \\
\left({ }^{\circ} \mathrm{C}\right)\end{array}$ & $\begin{array}{c}r_{\mathrm{e}} \\
(\AA)\end{array}$ & $\begin{array}{c}\sigma_{1} \\
(\AA)\end{array}$ & $\begin{array}{c}\sigma_{2} \\
(\AA)\end{array}$ & $\begin{array}{c}\sigma_{\mathrm{HS}} \\
(\AA)\end{array}$ & $\begin{array}{c}v_{\text {vib }} \\
\left(\mathrm{cm}^{-1}\right)\end{array}$ & $\begin{array}{c}f \\
(\text { dyne })\end{array}$ & $\begin{array}{c}g \\
(\text { dyne })\end{array}$ & $\begin{array}{c}a \\
\left(\mathrm{~cm}^{-1} /\right. \\
\left.\mathrm{g} / \mathrm{cm}^{3}\right)\end{array}$ & $\begin{array}{c}\mathrm{cm}^{-1} / \\
\left.\mathrm{g} / \mathrm{cm}^{3}\right)\end{array}$ \\
\hline $\mathrm{CH}_{4}$ & $\mathrm{C}-\mathrm{H}$ & 25 & 1.091 & 3.53 & 2.22 & 3.585 & 2916.5 & 0.005049 & -0.01047 & -4.92 & -34.43 \\
\hline
\end{tabular}

$r_{\mathrm{e}}$ - bond lengths, in low density vapour phase;

$\sigma_{1}, \sigma_{2}-$ pseudo-atomic hard sphere diameters;

$\sigma_{\mathrm{HS}}-$ effective molecular hard sphere diameter;

$v_{\text {vib }}$-vibrational resonance frequency in the low density vapor phase;

$f, g$-force constants are obtained from vibrational frequencies and extended Bager's rule correlations;

$a, b$-attractive force parameters are obtained by fitting the hard fluid model to high density frequency shifts measured in this study. 
Table 2 methane $v_{1}$ band position near zero pressure $\left(v_{0}\right)$ fitted for ten data sets of peak positions.

\begin{tabular}{ccccccccccc}
\hline & This & Hansen & Seitz & Fabre & Thieu & Lin & Lu & Shang & Jager* \\
& study & 2001 & 1996 & 1986 & 2000 & 2005 & 2007 & 2014 & Hester* \\
\hline$T$ & 25 & 22 & 23 & 19.85 & 24.85 & 22 & 22 & 22 & 24 & 30 \\
$\left({ }^{\circ} \mathrm{C}\right)$ & & & & & & & & & \\
$v_{0}$ & 2917.58 & 2916.96 & 2916.56 & 2916.52 & 2918.46 & 2917.62 & 2918.28 & 2918.24 & 2918.63 & 2917.33 \\
\hline
\end{tabular}

*Original data of Jager and Hester of Colorado School of Mines are cited from Table 1b of Lu et al. (2007). 
Table 3 Results of Raman analysis for the four pure $\mathrm{CH}_{4}$ fluid inclusions at $25^{\circ} \mathrm{C}$.

\begin{tabular}{cccccc}
\hline Inclusion & $\begin{array}{c}\text { Hosted } \\
\text { Mineral }\end{array}$ & $\begin{array}{c}v_{\text {true }} \\
\left(\mathrm{cm}^{-1}\right)\end{array}$ & $\begin{array}{c}D \\
\left(\mathrm{~cm}^{-1}\right)\end{array}$ & $\begin{array}{c}\text { Peak Width } \\
\text { at half height }\end{array}$ & $\begin{array}{c}\rho_{1} \\
\left(\mathrm{~g} / \mathrm{cm}^{3}\right)\end{array}$ \\
\hline A & Quartz & 2911.17 & -6.41 & 4.95 & 0.2719 \\
B & Quartz & 2911.18 & -6.40 & 4.98 & 0.2712 \\
C & Fluorite & 2916.84 & -0.74 & 2.51 & 0.026 \\
D & Fluorite & 2916.87 & -0.71 & 2.40 & 0.0249 \\
\hline
\end{tabular}

$v_{\text {true }}$ (in $\mathrm{cm}^{-1}$ ) is the calibrated peak position of sample fluid inclusion measured by Raman spectroscopy.

$D$ (in $\mathrm{cm}^{-1}$ ) represents the deviation of the measured peak posion of sample fluid inclusion from near zero density $v_{0}$.

Peak width at half hight is the measured Raman parameter, which can be used to determine the approximate range for methane density in fluid inclusions.

$\rho_{1}$ (in $\mathrm{g} / \mathrm{cm}^{3}$ ) stands for the calculated density of each natural $\mathrm{CH}_{4}$ fluid inclusion with the unified equation established in this study. 
Table 4 Results of micro-thermometry analysis for the four fluid inclusions.

\begin{tabular}{ccccc}
\hline Inclusion & $\begin{array}{c}\text { Hosted } \\
\text { Mineral }\end{array}$ & $\begin{array}{c}\text { Th } \\
\left({ }^{\circ} \mathrm{C}\right)\end{array}$ & $\begin{array}{c}\text { Homogenization } \\
(\text { phase })\end{array}$ & $\begin{array}{c}\rho_{2} \\
\left(\mathrm{~g} / \mathrm{cm}^{3}\right)\end{array}$ \\
\hline A & Quartz & -98.1 & Liquid & 0.2948 \\
B & Quartz & -97.9 & Liquid & 0.2941 \\
C & Fluorite & -116 & Vapor & 0.0224 \\
D & Fluorite & -117.2 & Vapor & 0.0213 \\
\hline
\end{tabular}

Th $\left({ }^{\circ} \mathrm{C}\right)$ is the homogenization temperature of each fluid inclusion measured with the heating-cooling stage.

$\rho_{2}$ was inferred from the homogenization temperature of methane with the computer programs FLUIDS for fluid inclusion studies developed by Bakker (2003). 


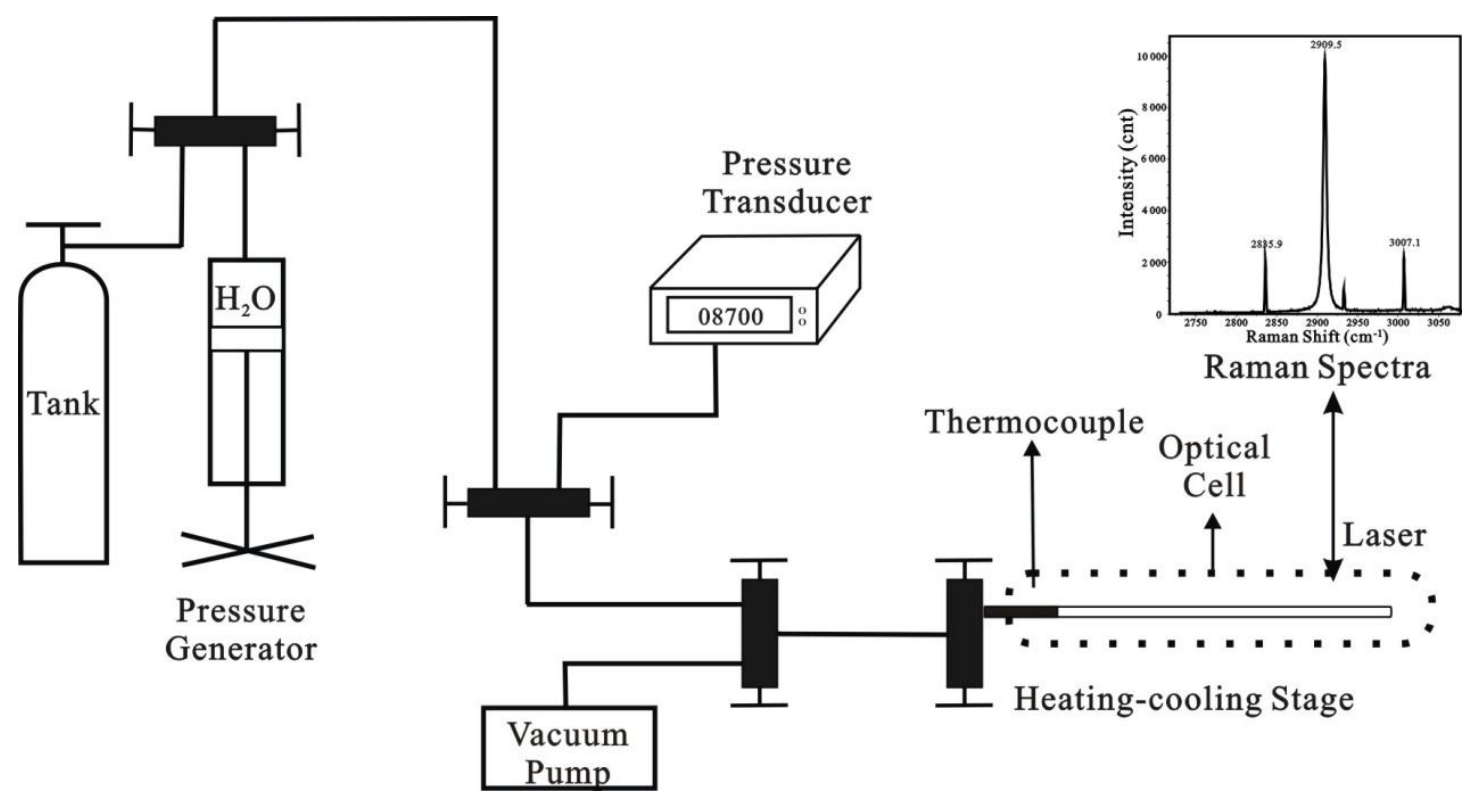

Fig.1 Schematic diagram of the experimental system (modified from Lu et al., 2007). 


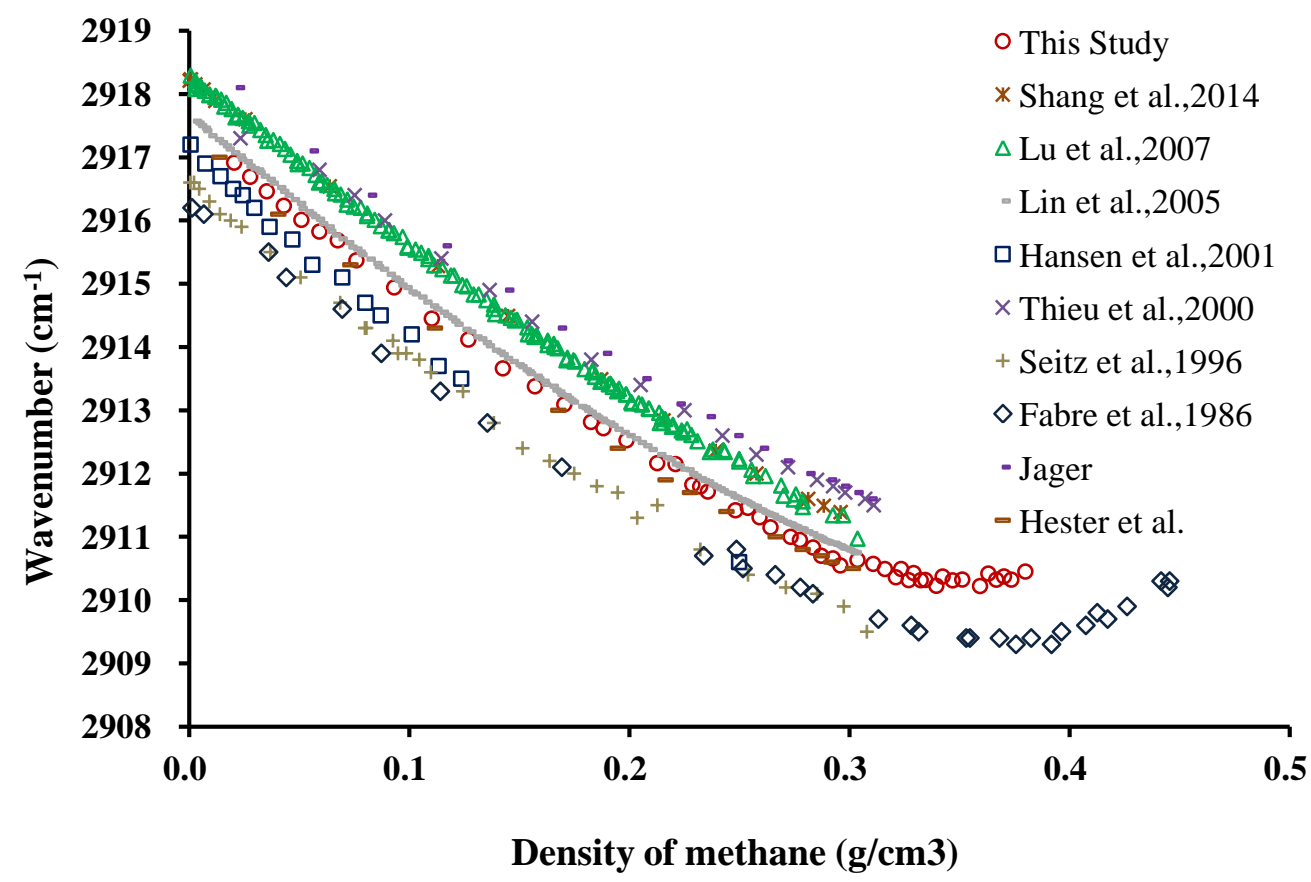

Fig.2 Raman shift position of C-H symmetric stretching band $\left(v_{1}\right)$ of methane from 10 available data sets as a function of density. The density of methane is calculated from the computer program of Mao et al. (2010). 


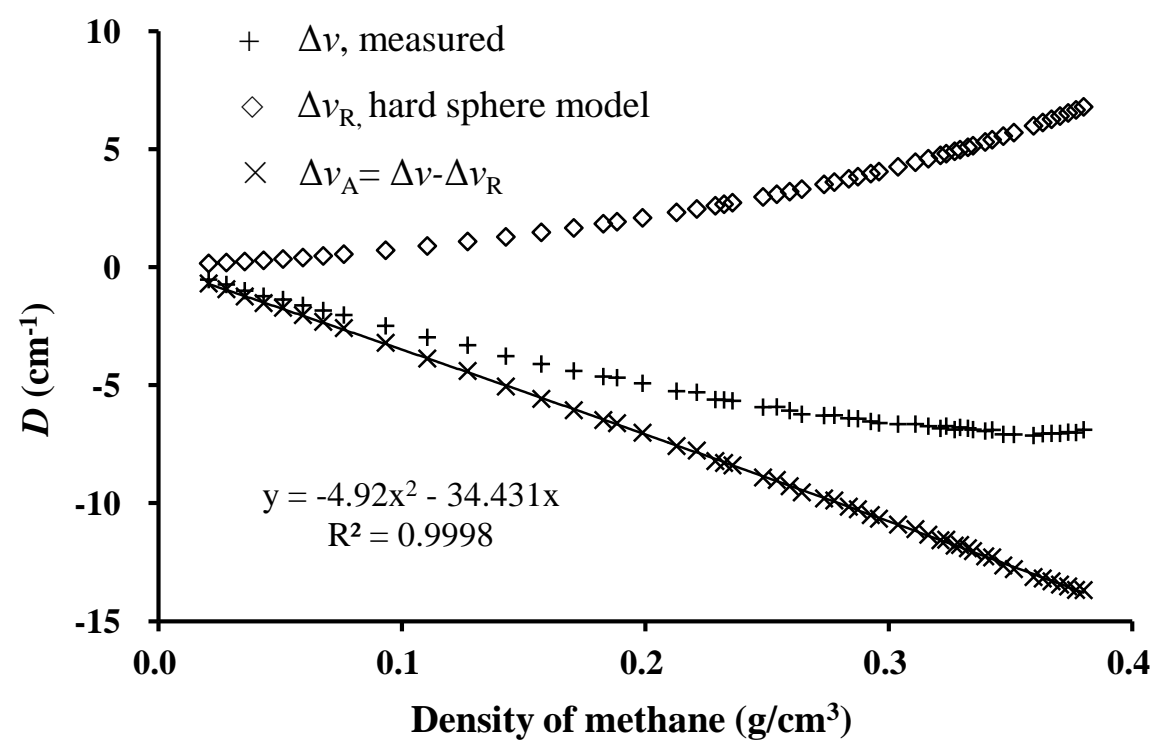

Fig.3 The measured total frequency shift $\Delta v$ in this study, the repulsive force frequency shift $\Delta v_{\mathrm{R}}$ calculated with hard sphere model, and the derived attractive force frequency shift $\Delta v_{\mathrm{A}}$, as a function of density of methane. 


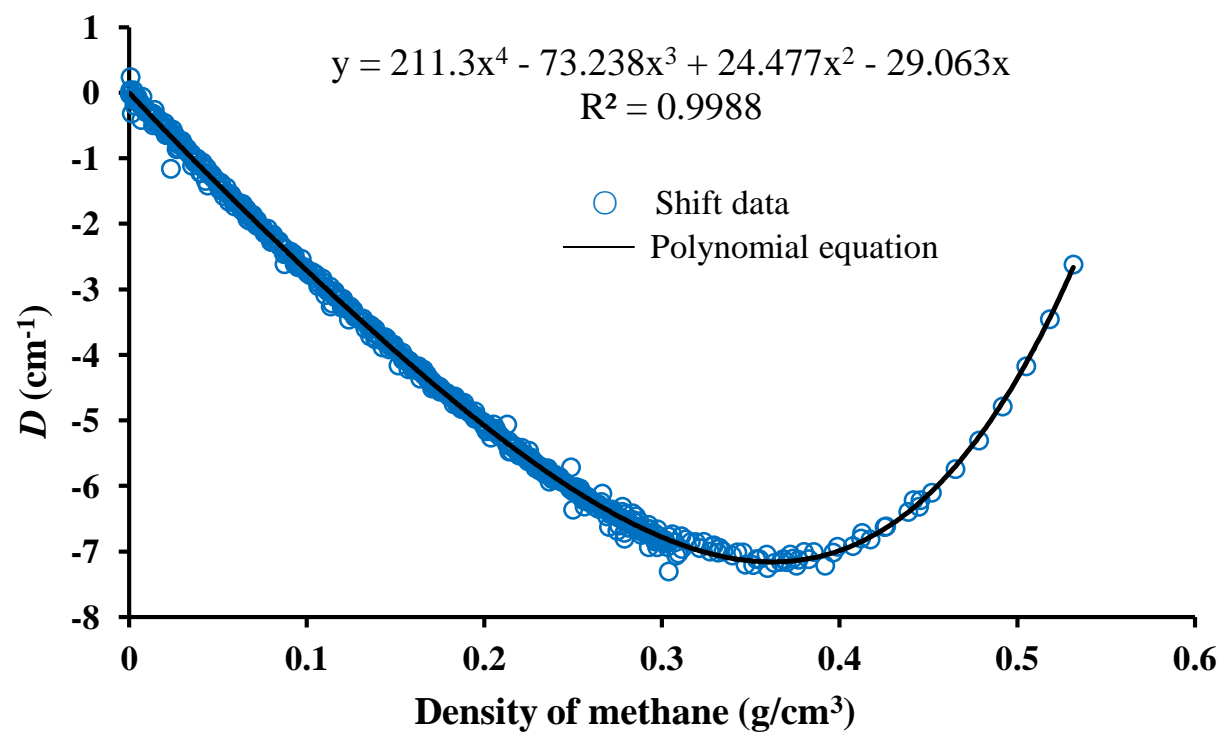

Fig.4 The polynomial equation fitted from ten data sets and theoretical calculation of the Raman shift. 


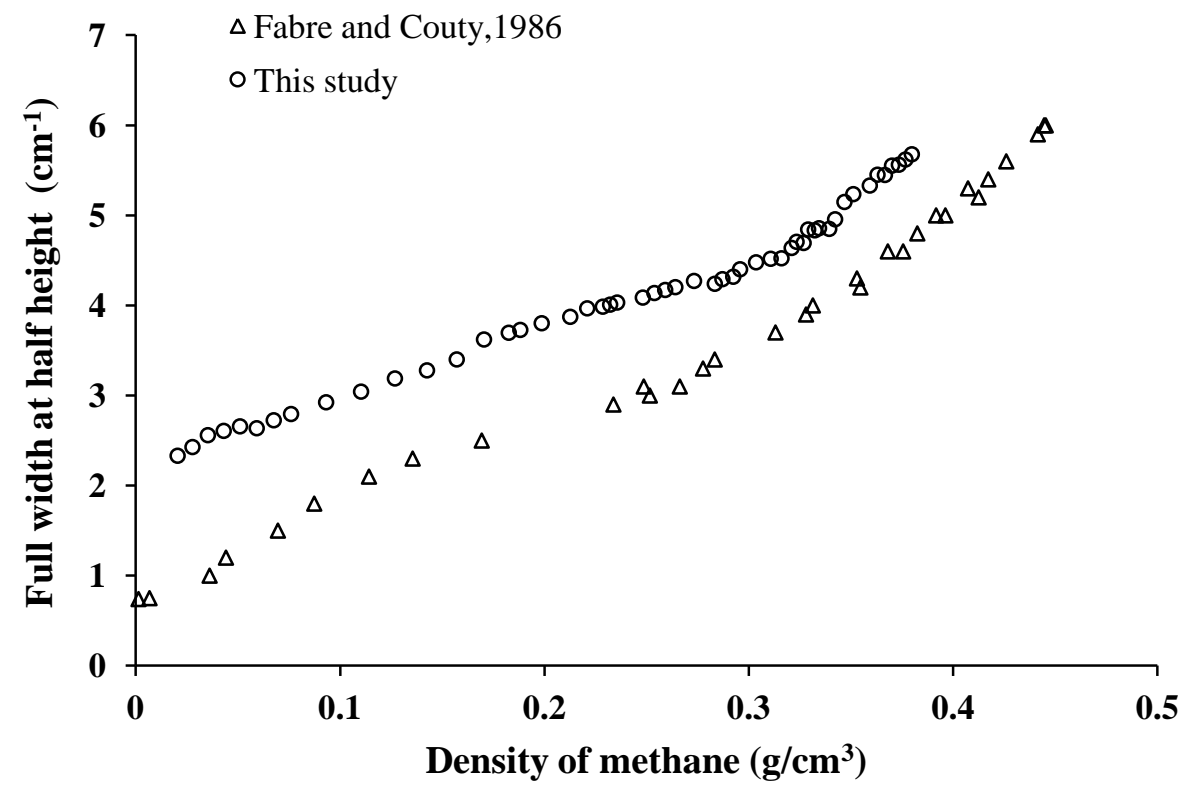

Fig.5 $\mathrm{CH}_{4}$ peak width at half height measured in this study at $25^{\circ} \mathrm{C}$, and the values observed by Fabre et al., (1986) at $19.85^{\circ} \mathrm{C}$. 

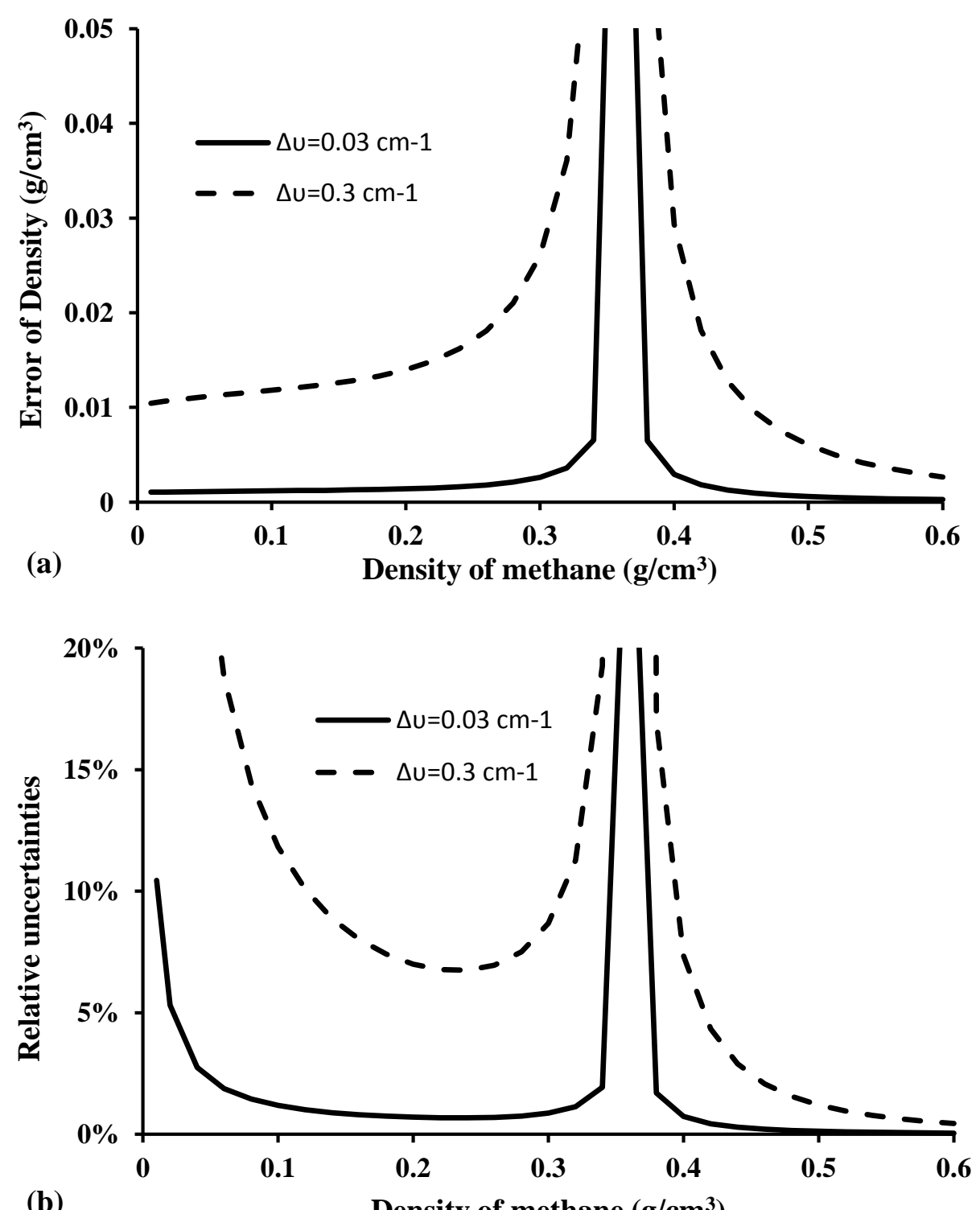

(b)

Density of methane $\left(\mathrm{g} / \mathrm{cm}^{3}\right)$

Fig. 6 Error of the calculated density (a) and the relative uncertainties (b), plotted with density of methane, for the different values of accuracy of $\mathrm{CH}_{4}$ peak position of 0.03 $\mathrm{cm}^{-1}$ (full line) and $0.3 \mathrm{~cm}^{-1}$ (dashed line). 
Figure 7

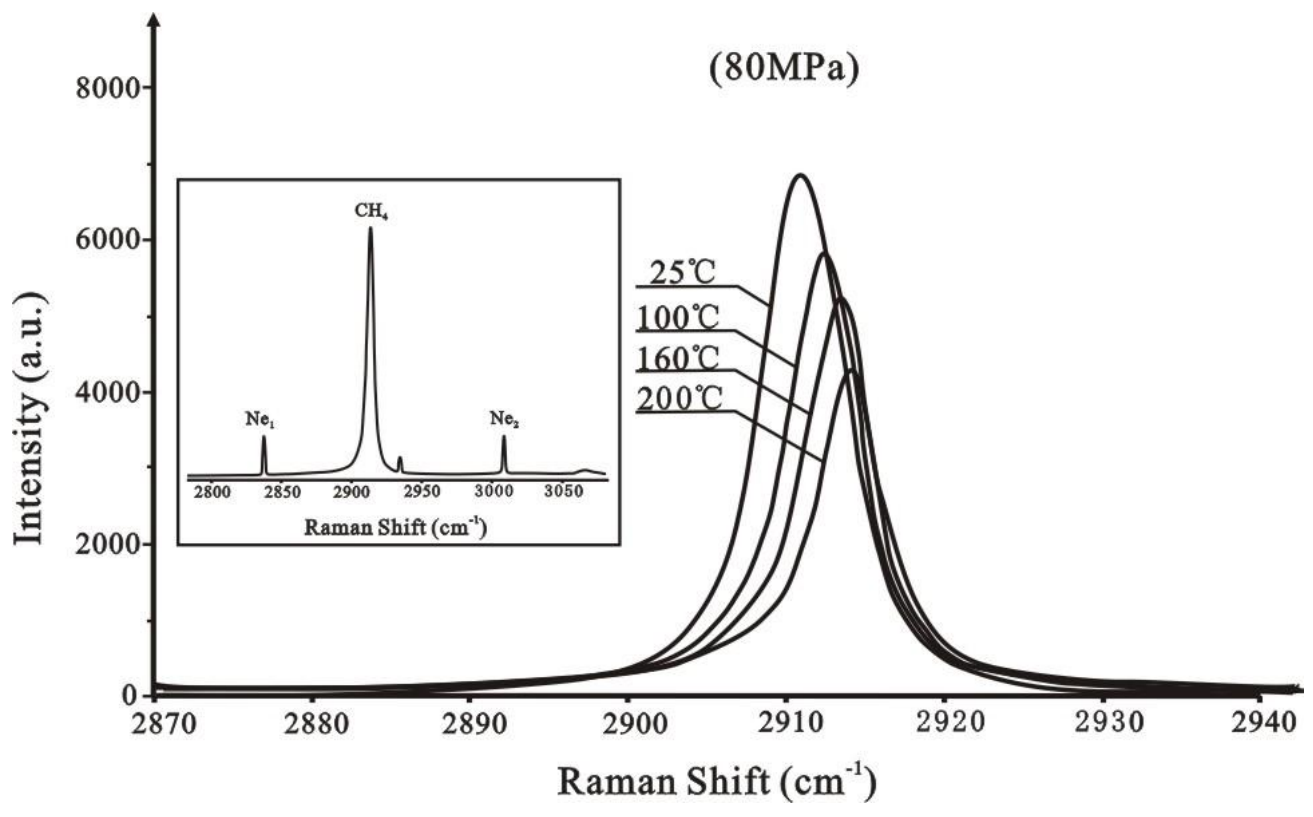

Fig. 7 Raman spectra of methane at $80 \mathrm{MPa}$ from 25 to $200{ }^{\circ} \mathrm{C}$. 


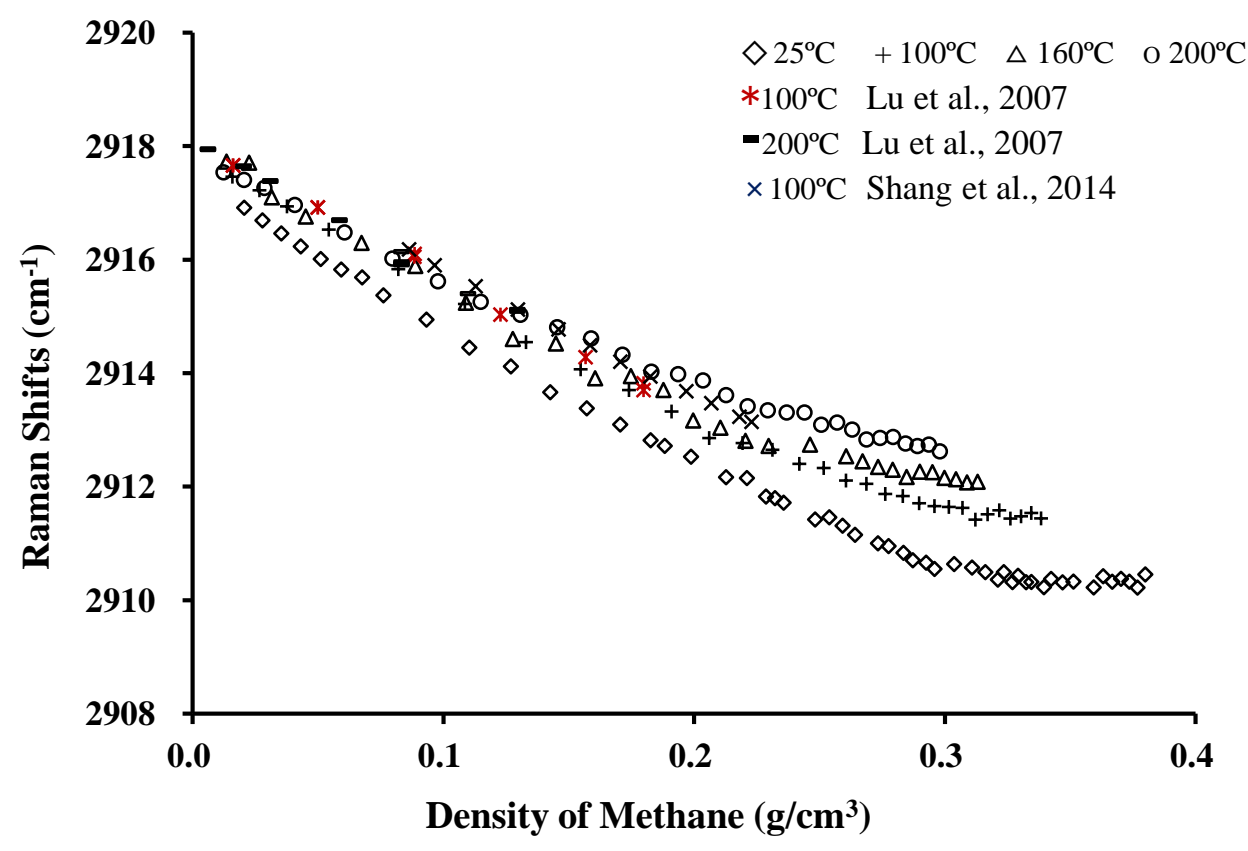

Fig.8 Raman position shift of methane at $25,100,160$, and $200{ }^{\circ} \mathrm{C}$, together with previous study of Lu et al.(2007) at 100 and $200^{\circ} \mathrm{C}$, and Shang et al.(2014) at $100^{\circ} \mathrm{C}$. 
Figure 9

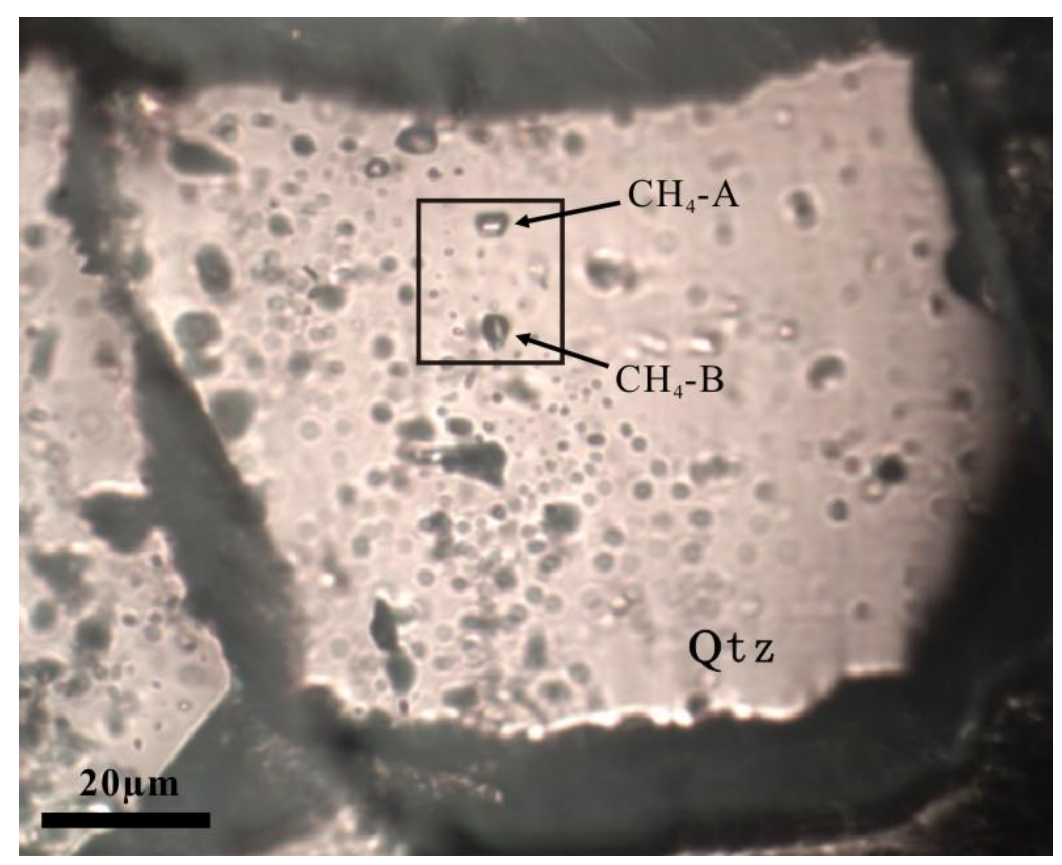

Fig. 9 Photograph of natural $\mathrm{CH}_{4}$ fluid inclusions (A and $\mathrm{B}$ in the square frame) in quartz from a MVT-Pb-Zn deposit basin under an Olympus $20 \times$ objective. 


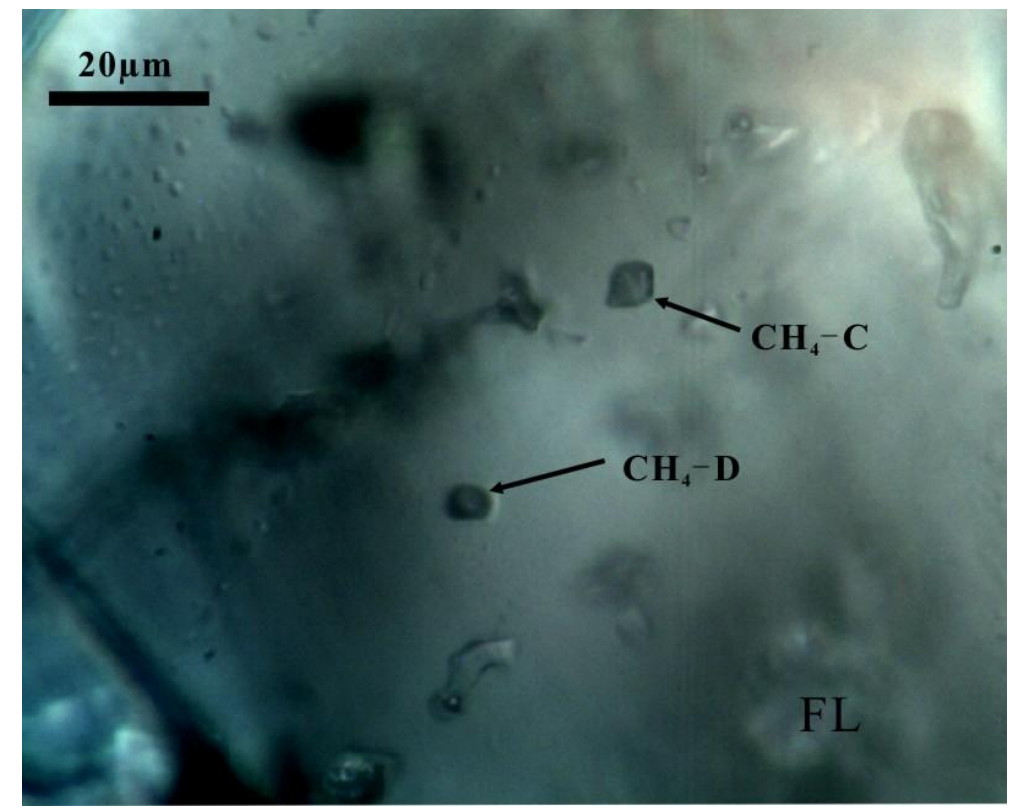

Fig. 10 Photographs of natural $\mathrm{CH}_{4}$ fluid inclusions $(\mathrm{C}$ and $\mathrm{D})$ in fluorite from a MVT-Pb-Zn deposit under an Olympus $50 \times$ objective. 

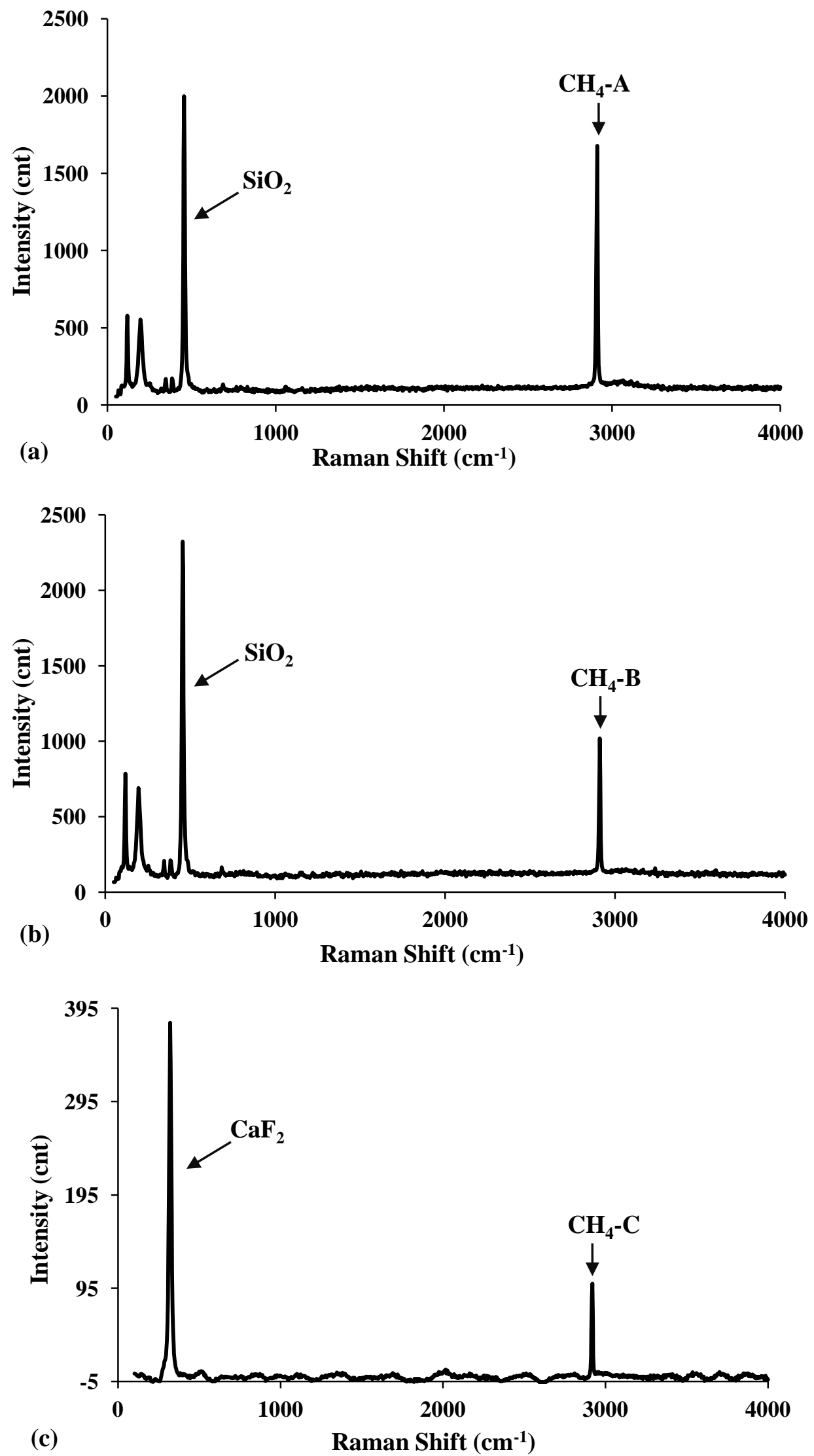


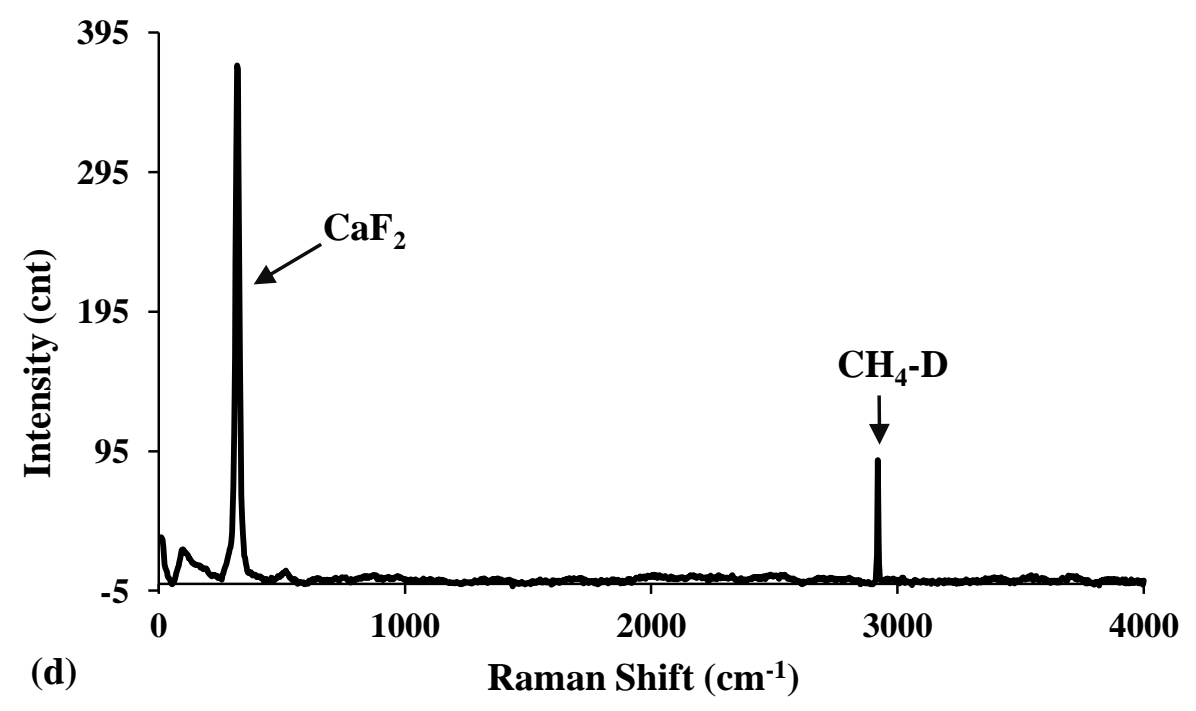

Fig. 11 Raman spectra of four natural fluid inclusions, collected with 300 groove $/ \mathrm{mm}$ grating. 

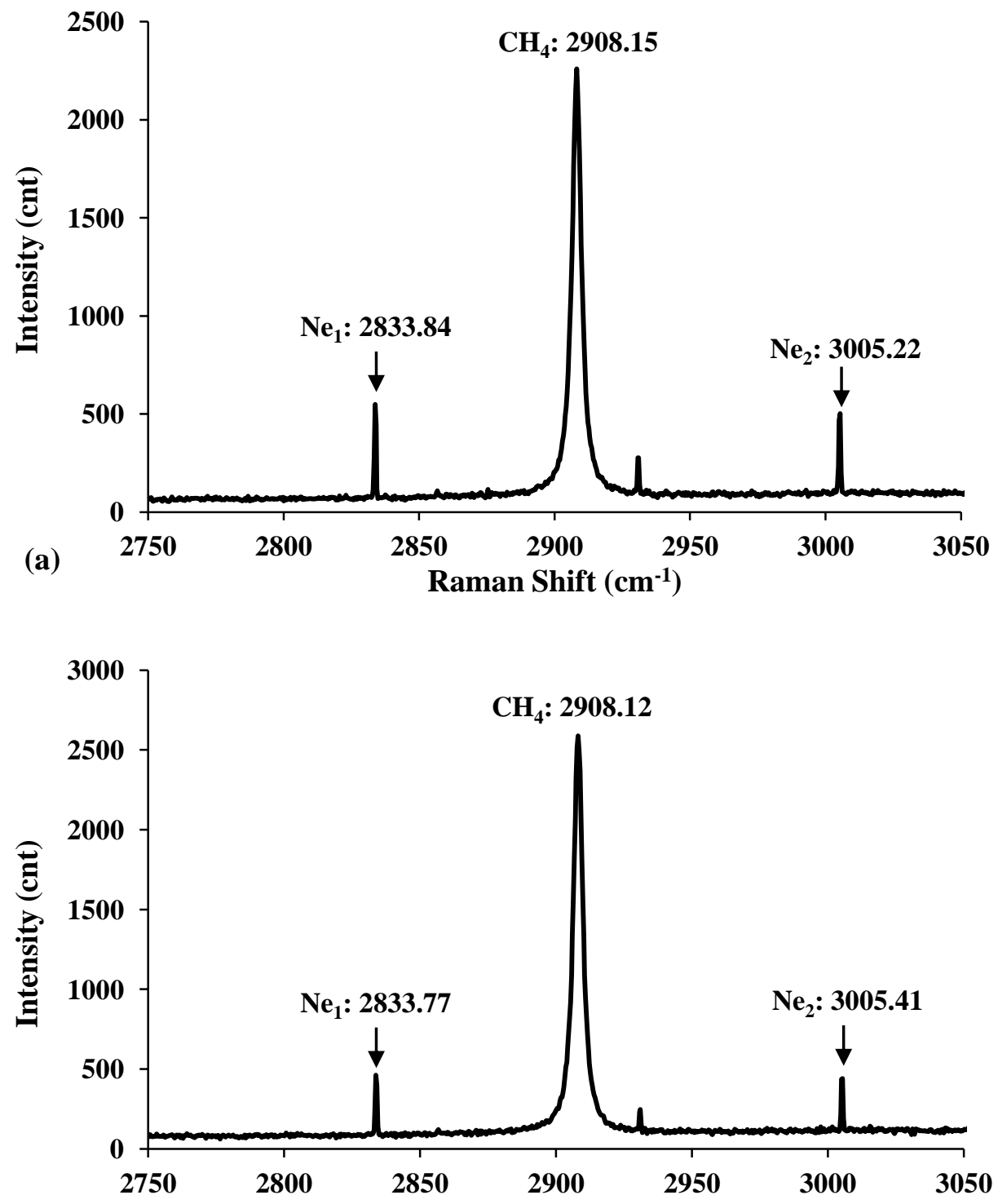

(b)

Raman Shift (cm-1) 

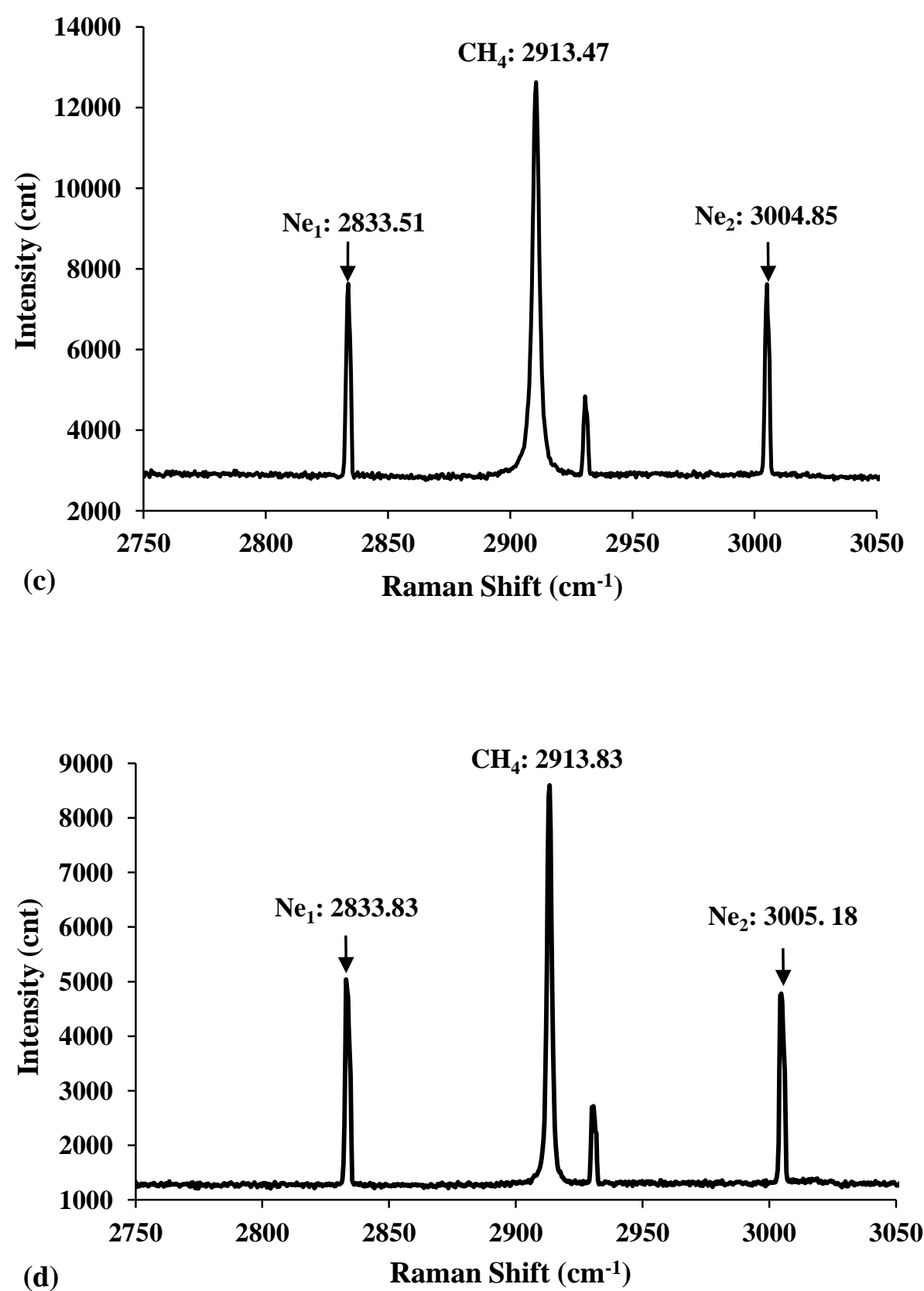

Fig.12 Raman spectra of four individual natural fluid inclusions collected with an 1800 groove/mm grating. 

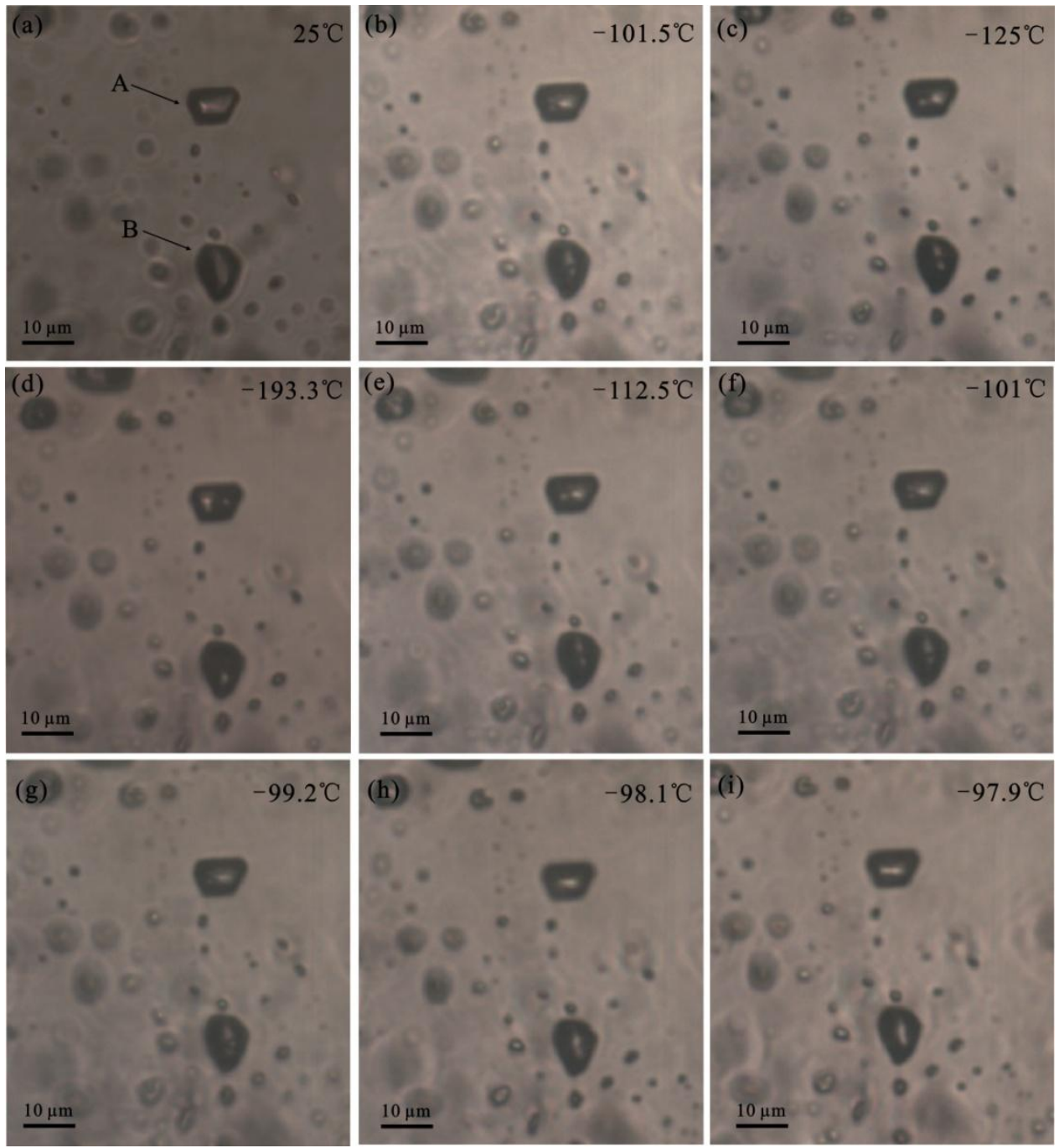

Fig. 13 Illustrations of low-temperature phase transition under an Olympus $50 \times$ objective (inclusion A and B).

(a) Mono-phase $\mathrm{CH}_{4}$ inclusions at $25{ }^{\circ} \mathrm{C}$; (b) Bubbles appeared when frozen to $-101.5{ }^{\circ} \mathrm{C}$; (c) Bubbles got bigger in size at $-125^{\circ} \mathrm{C}$ ); (d) Bubbles remained constant at $-193.3^{\circ} \mathrm{C}$; (e) Bubbles decreased in size when heated from $-193.3{ }^{\circ} \mathrm{C}$ to $-112.5^{\circ} \mathrm{C}$; (f) Bubbles became smaller $\left(-101{ }^{\circ} \mathrm{C}\right)$; (g) Bubbles almost disappeared $\left(-99.2{ }^{\circ} \mathrm{C}\right)$; (h) Bubble in A disappeared at $-98.1{ }^{\circ} \mathrm{C}$; (i) Bubble in B disappeared at $-97.9^{\circ} \mathrm{C}$. Both of inclusions A and B homogenized to the liquid phase. 